\title{
Specify Other Molecular Analysis
}

National Cancer Institute

\section{Source}

National Cancer Institute. Specify Other Molecular Analysis. NCI Thesaurus. Code C160765.

A request to specify the other molecular analysis type. 